\title{
GENERAL MODEL FOR ESTIMATION OF LONGSHORE TRANSPORT AT SHINGLE/MIXED BEACHES
}

\author{
Giuseppe R. Tomasicchio ${ }^{1}$, Felice D’Alessandro ${ }^{1}$, Giuseppe Barbaro ${ }^{2}$, \\ Francesco Ciardulli ${ }^{3}$, Antonio Francone ${ }^{1}$, Sahameddin Mahmoudi Kurdistani ${ }^{1}$
}

\begin{abstract}
In the present study, the accuracy of the GLT model (Tomasicchio et al., 2013) has been verified for the estimation of the Longshore Transport (LT) at shingle/mixed beaches. In order to verify the suitability of the GLT model in determining LT estimates at shingle beaches, without any further calibration, the comparison between the LT predictions and observations from two field data sets (Chadwick, 1989; Nicholls and Wright, 1991) has been considered. The comparison showed that the GLT predicted LT rates within a factor of 2 of the observed values. The predictive capability of the GLT has been also verified against an alternative general formula for the LT estimation at shingle beaches (Van Rijn, 2014). In addition, the suitability of the GLT model, even for the mixed beach case, has been assessed by means of the comparison between the LT prediction and the observation from a field experiment on a mixed sand and gravel beach at Hawke's Bay, on the east coast of New Zealand (Komar, 2010).
\end{abstract}

Keywords: Longshore transport; shingle beaches; mixed beaches; field and laboratory data; general model

\section{INTRODUCTION}

The formulation of a reliable estimate of the longshore transport (LT) rate is paramount in coastal engineering problems. Indeed, practical applications such as the design of dynamically stable reshaping or berm breakwaters, dispersion of the beach-fill and placed dredged material, beach nourishment projects, sedimentation rates in navigation channels, they all require accurate predictions of the LT. Such estimates should be based only on the use of valuable sediment transport models underpinned by reliable transport measurements (Van Wellen et al., 1998).

To date, sandy beaches have received the bulk of the attention. The number of documented studies and available data on sandy beaches is, therefore, considerable and ranges from analytical/numerical models and laboratory tests to large scale field experiments. In strong contrast is the moderate attention which coarser grained (i.e. shingle) and, in particular, mixed sand and gravel beaches have received.

Presently, there is a growing interest in properly defining the morphological processes of a shingle/mixed beach due to the increased use of coarse sediments in the artificial recuperation of eroded beaches, as they are characterized by a higher hydraulic roughness and provide a better defense to the forcing processes induced during storm events (Tomasicchio et al., 2010; Bramato et al., 2012).

Generally cobbles roll, coarse sand moves by a series of hops or leaps (i.e. saltation) and fine sand and silt move in suspension (Dake, 1972). Longshore transport (LT) at shingle beaches is characterized by a steep beach slope, typically $1: 8$, which encourages waves to form rapidly plunging or surging breakers close to the shoreline; thus, most of the energy dissipation is restricted to a narrow region that includes the swash zone (Van Wellen et al., 2000). Well sorted coarse sediments also exhibit a larger permeability compared to the sand; this allows larger infiltration of water during the swash run-up, which weakens the backwash and can be identified with the formation of the berm at the run-up maximum. These phenomena are rather different than on typical sandy beaches for which most popular formulae (e.g. Kamphuis, 1991; U.S. Army Corps of Engineers, USACE, 1984) have been developed.

Although several shingle beach field experiments have been conducted in the past, insufficient information has been obtained to make them useful to calibrate LT formulae; in fact, most published sources of shingle beach data failed on the lack of concurrent wave measurements and transport rates. To our knowledge, only two field data sets satisfy the criteria of available wave conditions (height, period and angle), transport rates, beach slopes and grain size: Shoreham-by-Sea (Chadwick, 1989) and Hurst Castle Spit (Nicholls and Wright, 1991), both in the UK.

The General Longshore Transport (GLT) model (Tomasicchio et al., 2013) and the Van Rijn (2014) expression represent the only two general formulae in literature for the estimation of LT at sand, gravel and shingle beaches. In particular, the GLT model is based on an energy flux approach combined with an empirical relationship between the wave induced forcing and the number of moving elements. Tomasicchio et al. (2015) showed that GLT gives a good agreement even for the LT at dynamically stable berm reshaping breakwaters.

\footnotetext{
${ }^{1}$ Department of Engineering, University of Salento, Ecotekne, via Monteroni, 73100, Lecce, Italy

2 DICEAM, Mediterranea University of Reggio Calabria, via Graziella 1, 89060 Reggio Calabria, Italy

${ }^{3}$ CWP Engineering - Marina Plaza, Dubai Marina, Dubai, United Arab Emirates
} 


\section{TWO GENERAL FORMULAE FOR THE ESTIMATION OF LT}

\section{The GLT model}

A general model is defined relating LT due to oblique wave attacks to the mobility level of the units composing the coastal structure (Lamberti and Tomasicchio, 1997). The LT model is based on the assumption that movements statistics is affected by obliquity only through an appropriate mobility index and that the units move during up- and down-rush with the same obliquity of breaking and reflected waves at the breaker depth (Lamberti and Tomasicchio, 1997; Tomasicchio et al., 1994). A particle will pass through a certain control section in a small time interval $\Delta t$ if and only if it is removed from an updrift area of extension equal to the longitudinal component of the displacement length, $l_{\mathrm{d}}$ $\sin \theta_{\mathrm{d}}$, where $l_{\mathrm{d}}$ is the displacement length and $\theta_{\mathrm{d}}$ is its obliquity (Fig. 1).

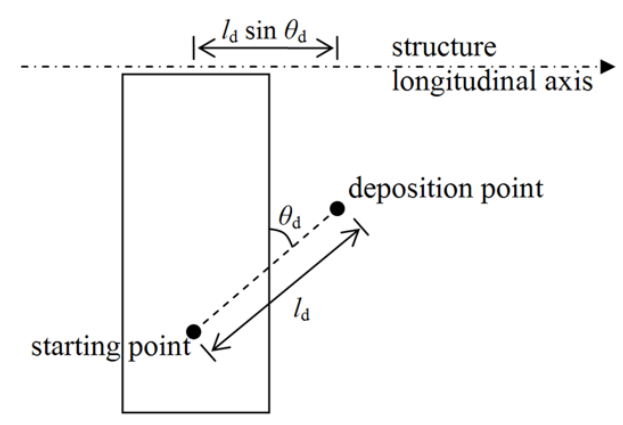

Figure 1. Definition sketch for the GLT model

This process description is particularly true when considering the wave obliquity, the up-rush and related LT at the swash zone. Assuming that the displacement obliquity is equal to the characteristic wave obliquity at breaking $\left(\theta_{\mathrm{d}}=\theta_{\mathrm{k}, \mathrm{b}}\right)$, and that a number $N_{\mathrm{od}}$ of particles removed from a nominal diameter, $D_{\mathrm{n} 50}$, wide strip moves under the action of 1000 waves, then the number of units passing a given control section in one wave is:

$$
S_{N}=\frac{l_{d}}{D_{n 50}} \cdot \frac{N_{o d}}{1000} \sin \theta_{k, b}=f\left(N_{s}^{* *}\right)
$$

where:

$$
N_{s}^{* *}=\frac{H_{k}}{C_{k} \Delta D_{n 50}}\left(\frac{s_{m, 0}}{s_{m, k}}\right)^{-1 / 5}\left(\cos \theta_{0}\right)^{2 / 5}
$$

is the modified stability number (Lamberti and Tomasicchio, 1997) with: $H_{\mathrm{k}}=$ characteristic wave height; $C_{\mathrm{k}}=H_{\mathrm{k}} / H_{\mathrm{s}}$ where $H_{\mathrm{s}}=$ significant wave height; $\theta_{0}=$ offshore wave obliquity; $s_{\mathrm{m}, 0}=$ mean wave steepness at offshore conditions and $s_{\mathrm{m}, \mathrm{k}}=$ characteristic mean wave steepness (assumed equal to 0.03). Lamberti and Tomasicchio (1997) reported that $H_{\mathrm{k}}$ is to be considered equal to $H_{1 / 50}$, but $H_{2 \%}$ can also be adopted. In the first case: $C_{\mathrm{k}}=1.55$, in the second case: $C_{\mathrm{k}}=1.40$. The second factor in Eq. (2) is such that $N_{\mathrm{s}}^{* *} \cong N_{\mathrm{s}}$ for $\theta_{0}=0$ if $s_{\mathrm{m}, 0}=s_{\mathrm{m}, \mathrm{k}}$. For a berm breakwater, strict threshold conditions correspond to $N_{\mathrm{s}}^{* *} \cong 2$.

In the case of head-on wave attacks, under the assumption that, offshore the breaking point, the wave energy is negligible and that waves break as shallow water waves, the following relation holds:

$$
F=1 / 8 \rho g H_{0}^{2} c_{g, 0}^{2}=1 / 8 \rho g H_{b}^{2} c_{g, b}^{2}
$$

where $c_{\mathrm{g}, 0}$ is the offshore wave group celerity, $c_{\mathrm{g}, \mathrm{b}}$ is the wave group celerity at breaking, $H_{0}$ is the offshore wave height and $H_{\mathrm{b}}$ is the wave height at breaking. Considering Eq. (3) and $c_{g, 0}=1 / 2 \sqrt{g / k_{0}}$ , where $k_{0}$ is the offshore wave number, the longshore component of $F$ can be written as:

$$
F \cos \theta \propto H_{0}^{5 / 2} s_{0}^{-1 / 2} \cos \theta
$$

and $\cos \theta$ is present in Eq. (2) with a power $2 / 5$. 
Eq. (3) related to $\gamma_{\mathrm{b}}=H_{\mathrm{b}} / h_{\mathrm{b}}$ imply:

$$
H_{b}=H_{0}\left(\frac{\gamma_{b}}{4 k_{0} H_{0}}\right)^{1 / 5}=q H_{0} s_{0}^{-1 / 5}
$$

Komar and Gaughan (1972) found the best agreement with field and laboratory data assuming $\gamma_{\mathrm{b}}=$ 1.42 or the proportionality constant $q=0.56$. It follows that, considering the characteristic wave height at breaking, $H_{\mathrm{k}, \mathrm{b}}$, and $s_{\mathrm{m}, 0}=s_{\mathrm{m}, \mathrm{k}}=0.03, N_{\mathrm{s}}^{* *}$ can be also written as:

$$
N_{s}^{* *} \cong \frac{0.89 H_{k, b}}{C_{k} \Delta D_{n 50}}
$$

and it can be noticed that, according to the proposed LT model, the relevant parameter is the onshore energy flux and that the proposed model belongs to the category based on an energy flux approach.

According to the refraction theory for plane and monotonically decreasing profiles, $H_{\mathrm{k}, \mathrm{b}}$ and $\sin$ $\theta_{\mathrm{k}, \mathrm{b}}$, can be evaluated as in the following (Lamberti and Tomasicchio, 1997; Tomasicchio et al., 1994):

$$
\begin{gathered}
H_{k, b}=\left(H_{k}^{2} c_{g} \cos \theta \sqrt{\gamma_{b} / g}\right)^{2 / 5} \\
\sin \theta_{k, b}=\frac{c_{k, b}}{c} \sin \theta \\
c_{k, b}=\sqrt{g H_{k, b} / \gamma_{b}}
\end{gathered}
$$

where $c_{\mathrm{k}, \mathrm{b}}$ is the characteristic wave celerity at breaking depth.

The displacement length is calculated as (Lamberti and Tomasicchio, 1997):

$$
l_{d}=\frac{\left(1.4 N_{s}^{* *}-1.3\right)}{\tanh ^{2}(k h)} D_{n 50}
$$

with $k=$ wave number.

$N_{\text {od }}$ has been determined following a calibration procedure based on the least-squares method taking into account the full data base. In particular, two different approximating functions are considered; to accommodate the calibration procedure, $N_{\text {od }}$ values calculated from measured data are partitioned in two subintervals. The first interval refers to $N_{\mathrm{s}}^{* *} \leq 23$ : from berm breakwaters to gravel beaches. The second one relates to $N_{\mathrm{s}}^{* *}>23$ : the interval for sandy beaches. For $N_{\mathrm{s}}{ }^{* *} \leq 23$, a third order polynomial approximating function provides a satisfactory agreement as shown by Tomasicchio et al. (2007). For $N_{\mathrm{s}}^{* *}>23$ a good agreement is given by a linear regression in log-log plane.

After the adopted calibration procedure $N_{\text {od }}$ is given as:

$$
N_{o d}= \begin{cases}20 N_{s}^{* *}\left(N_{s}^{* *}-2\right)^{2} & N_{s}^{* *} \leq 23 \\ \exp \left[2.72 \ln \left(N_{s}^{* *}\right)+1.12\right] & N_{s}^{* *}>23\end{cases}
$$

The estimated correlation coefficient results equal to 0.89 for $N_{\mathrm{s}}^{* *} \leq 23$, and 0.92 for $N_{\mathrm{s}}^{* *}>23$, respectively.

LT rate can be also expressed in terms of $\left[\mathrm{m}^{3} / \mathrm{s}\right]$ as in the following:

with $T_{\mathrm{m}}=$ mean wave period.

$$
Q_{L T}=\frac{S_{n} D_{n 50}^{3}}{T_{m}}
$$

\section{Van Rijn (2014) formula}

The process-based CROSMOR-2013 model has been used to determine the effects of wave period, grain size, beach/surf zone slope and type of waves (wind waves or swell waves). The CROSMOR2013 model is an updated version of the CROSMOR-2004 model (Van Rijn, 2006/2012, 2007) and computes both the cross-shore and longshore transport rates. The model has been extensively validated by Van Rijn et al. (2003) and (2011). 
The LT has been found to be proportional to wave height to the power $3.1\left(\approx \mathrm{H}^{3.1}\right)$, to grain size to the power $-0.6\left(\approx D_{n 50}^{-0.6}\right)$ and to beach slope to the power $0.4\left(\approx \tan \beta^{0.4}\right)$. Based on the CROSMOR2013 results, it is assumed that the longshore transport rate $\left(Q_{\mathrm{t} \text {,mass }}\right.$ in $\left.\mathrm{kg} / \mathrm{s}\right)$ can be represented by the following (dimensionally correct) expression:

$$
Q_{t, \text { mass }}=\alpha M
$$

with: $M=$ mobility parameter (in $\mathrm{kg} / \mathrm{s})=\rho_{\mathrm{s}} \mathrm{g}^{0.5}(\tan \beta)^{0.4}\left(D_{\mathrm{n} 50}\right)^{-0.6}\left(H_{\mathrm{s}, \mathrm{br}}\right)^{3.1} \sin \left(2 \theta_{\mathrm{br}}\right), \rho_{\mathrm{s}}=$ sediment density $\left(\mathrm{kg} / \mathrm{m}^{3}\right), g=$ acceleration due to gravity $\left(\mathrm{m} / \mathrm{s}^{2}\right), \tan \beta=$ slope of beach $/$ surf zone, $D_{\mathrm{n} 50}=$ median grain size $(\mathrm{m}), H_{\mathrm{s}, \mathrm{br}}=$ significant wave height at breaker line $(\mathrm{m}), \theta_{\mathrm{br}}=$ wave angle to shore normal at breaker line (degrees), $\alpha=$ calibration coefficient $=0.00018$. Thus:

$$
Q_{t, \text { mass }}=0.00018 \rho_{s} g^{0.5}(\tan \beta)^{0.4}\left(D_{n 50}\right)^{-0.6}\left(H_{s, b r}\right)^{3.1} \sin \left(2 \theta_{b r}\right)
$$

Eq. (14) does not account for the effect of the wave period on the longshore transport rate.

\section{SHINGLE BEACHES DATA}

Several field investigations on LT at shingle beaches have been conducted along the UK coastline. In the present paper, two field data sets have been adopted: Shoreham-by-Sea (Chadwick, 1989) measured by traps and Hurst Castle Spit (Nicholls and Wright, 1991) measured by tracers. In Chadwick (1989) and Nicholls and Wright (1991) LT rates are given as mass transport rate per unit time $\left(\mathrm{QLT}_{\text {, }}\right.$ in $\mathrm{kg} / \mathrm{s})$. These values have been converted to the LT rates in volume per unit time (QLT in $\left.\mathrm{m}^{3} / \mathrm{s}\right)$ by using QLT $=\mathrm{QLT}_{, \mathrm{m}} /(1-p) \rho_{\mathrm{s}}$ with $p=$ porosity factor $(0.45$ for shingle). Table 1 lists the observed data ( $n=6$ data points; $T_{\mathrm{p}}=$ peak wave period; $\mathrm{Q}_{\mathrm{LT}, \mathrm{o}}=\mathrm{LT}$ rate in volume per unit time, observed).

\begin{tabular}{|c|c|c|c|c|c|c|c|c|}
\hline \multicolumn{7}{|c|}{ Table 1. Longshore transport field data (Chadwick, 1989; Nicholls and Wright, 1991). } \\
\hline Location & $n(-)$ & $D_{\mathrm{n} 50}(\mathrm{~mm})$ & $\rho_{\mathrm{s}}\left(\mathrm{kg} / \mathrm{m}^{3}\right)$ & $\tan \beta$ & $H_{\mathrm{s}, \mathrm{br}}(\mathrm{m})$ & $\theta_{\mathrm{br}}\left(^{\circ}\right)$ & $T_{\mathrm{p}}(\mathrm{s})$ & $\mathrm{QLT}_{\mathrm{o}}\left(\mathrm{m}^{3} / \mathrm{s}\right)$ \\
\hline \multirow{3}{*}{ Shoream, UK } & \multirow{3}{*}{4} & 20 & 2650 & 0.1 & 0.30 & 15 & 3 & $3.1 \mathrm{E}-05$ \\
\cline { 3 - 9 } & & 20 & 2650 & 0.1 & 0.35 & 15 & 3 & $1.1 \mathrm{E}-04$ \\
\cline { 3 - 9 } & & 20 & 2650 & 0.1 & 0.40 & 15 & 3 & $1.9 \mathrm{E}-04$ \\
\cline { 3 - 9 } & & 20 & 2650 & 0.1 & 0.70 & 15 & 4 & $3.1 \mathrm{E}-04$ \\
\hline \multirow{2}{*}{ Hurst Castle Spit, UK } & \multirow{2}{*}{2} & 32 & 2650 & 0.1 & 0.75 & 15 & 6 & $3.1 \mathrm{E}-04$ \\
\cline { 3 - 9 } & & 32 & 2650 & 0.1 & 1.00 & 15 & 6 & $9.4 \mathrm{E}-04$ \\
\hline
\end{tabular}

Van Hijum and Pilarczyk (1982) conducted a limited number of laboratory 3D experiments on gravel sized beaches at the Delft Hydraulics laboratory. LT has been measured from beach profile surveys using the principle of continuity of sediments in the longshore direction. In Van Hijum and Pilarczyk (1982) LT rates are given as the ratio $S(x) / g D_{90}^{2} T_{S}$ where: $S(x)=$ component of resulting material transport, $S$, parallel to the beach $\left(\mathrm{m}^{3} / \mathrm{s}\right) ; D_{90}=90 \%$ representative grain diameter $\left(D_{90}\right.$ $\left.=1,2 D_{\mathrm{n} 50}\right) ; T_{\mathrm{s}}=$ significant wave period. Information on wave characteristics are given offshore the breaker line (Table 2).

\begin{tabular}{|c|c|c|c|c|c|c|c|}
\hline \multicolumn{6}{|c|}{ Table 2. Longshore transport laboratory data (Van Hijum and Pilarczyk, 1982). } \\
\hline$n(-)$ & $D_{\mathrm{n} 50}(\mathrm{~mm})$ & $\rho_{\mathrm{s}}\left(\mathrm{kg} / \mathrm{m}^{3}\right)$ & $\tan \beta$ & $H_{\mathrm{s}, 0}(\mathrm{~m})$ & $\theta_{0}\left({ }^{\circ}\right)$ & $T_{\mathrm{p}}(\mathrm{s})$ & $\mathrm{QLT}_{\mathrm{L}, \mathrm{o}}\left(\mathrm{m}^{3} / \mathrm{s}\right)$ \\
\hline \multirow{4}{*}{} & 4 & 2570 & 0.2 & 0.076 & 30 & 1.18 & $1.1 \mathrm{E}-05$ \\
\cline { 2 - 8 } & 4 & 2570 & 0.2 & 0.088 & 30 & 1.00 & $1.0 \mathrm{E}-05$ \\
\cline { 2 - 8 } & 4 & 2570 & 0.2 & 0.080 & 30 & 1.44 & $2.1 \mathrm{E}-05$ \\
\cline { 2 - 8 } & 4 & 2570 & 0.2 & 0.129 & 30 & 1.46 & $8.7 \mathrm{E}-05$ \\
\cline { 2 - 8 } & 4 & 2570 & 0.2 & 0.090 & 30 & 1.43 & $2.3 \mathrm{E}-05$ \\
\cline { 2 - 8 } & 4 & 2570 & 0.2 & 0.124 & 30 & 1.45 & $5.6 \mathrm{E}-05$ \\
\cline { 2 - 8 } & 4 & 2570 & 0.2 & 0.085 & 30 & 1.80 & $2.8 \mathrm{E}-05$ \\
\cline { 2 - 8 } & 4 & 2570 & 0.2 & 0.124 & 30 & 1.81 & $8.0 \mathrm{E}-05$ \\
\cline { 2 - 8 } & 4 & 2570 & 0.2 & 0.119 & 30 & 2.05 & $7.1 \mathrm{E}-05$ \\
\cline { 2 - 8 } & 4 & 2570 & 0.2 & 0.165 & 30 & 2.06 & $2.0 \mathrm{E}-04$ \\
\hline
\end{tabular}

For the shingle beach case, calibration of the Van Rijn (2014) formula made use of data from 
Chadwick (1989) and Nicholls and Wright (1991).

Calibration of the GLT model (Tomasicchio et al., 2013) made use of different field and laboratory data ranging from sandy beaches till reshaping berm breakwaters; in particular, for the shingle beaches case, laboratory data from Van Hijum and Pilarczyk (1982) have been adopted.

\section{GLT VERIFICATION}

Although the GLT model has been proposed and verified for an extensive range of conditions, from sandy beaches till reshaping or berm breakwaters, its verification, without any further calibration, is now particularly focused to the case of shingle beaches: for this purpose, the Chadwick (1989) and Nicholls and Wright (1991) field data have been considered. Fig. 2 shows the relationship between the calculated $S_{\mathrm{N}} / \sin \theta_{\mathrm{k}, \mathrm{b}}$ versus $N_{\mathrm{s}}^{* *}$ (Lamberti and Tomasicchio, 1997). With reference to the range of variation of $N_{\mathrm{s}}^{* *}$, the second region refers to the shingle beaches (cobbles and gravel, $6<N_{\mathrm{s}}^{* *}<23$ ); this region is now reporting a larger number of data (Chadwick, 1989; Nicholls andWright, 1991) which allows to confirm that the GLT model gives reliable estimates of the longshore transport at shingle beaches.

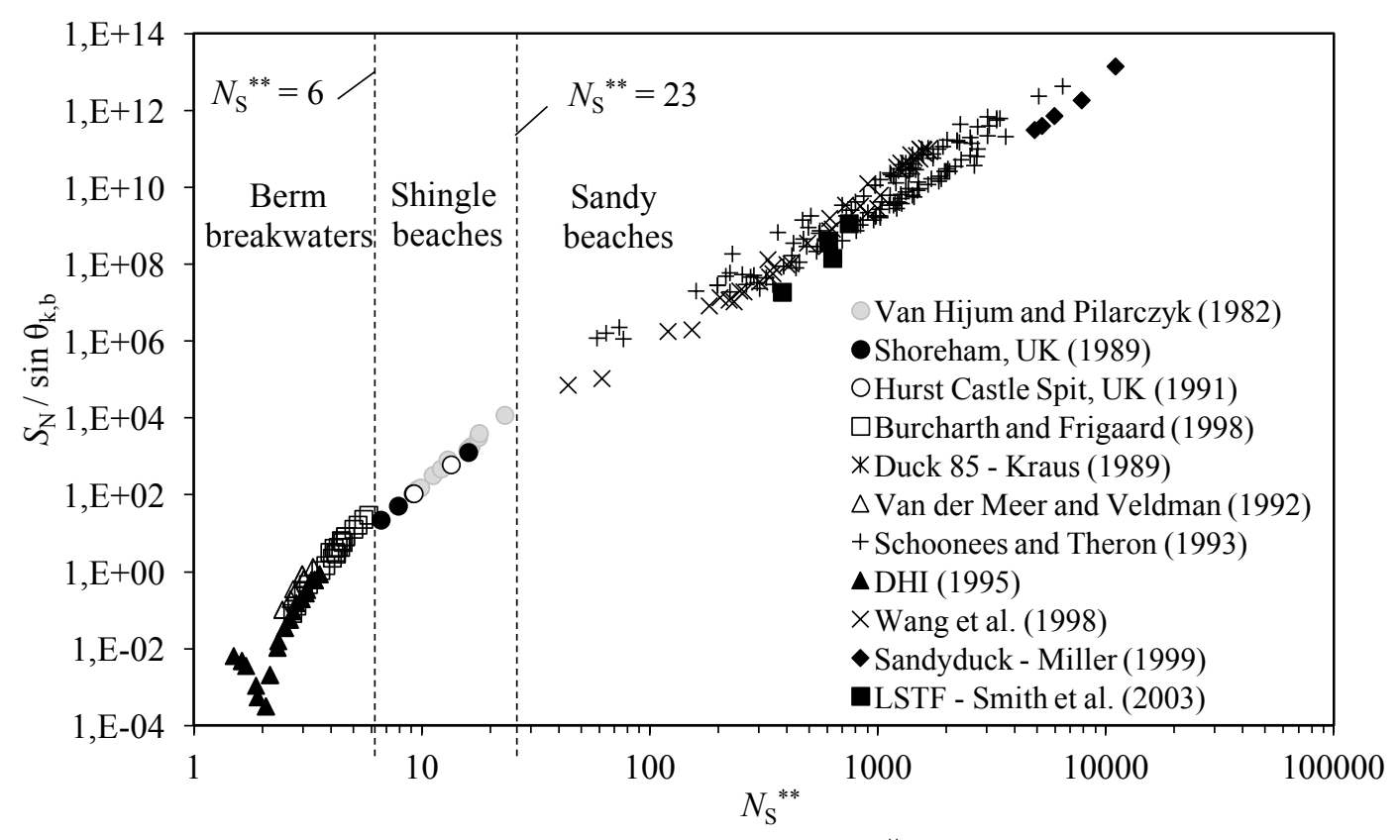

Figure 2. Calculated $S_{N} / \sin \theta_{k, b}$ versus $N_{s}^{* *}$.

In order to have a measure of the scatter, according to Bayram et al. (2007), a mean discrepancy ratio, $d_{\mathrm{r}}$, has been assigned to the GLT model given by the percentage of the calculated LT, $Q_{\mathrm{LT}, \mathrm{c}}$, within an interval of confidence in the range between 0.5 and 2 of the observed LT, $Q_{\mathrm{LT}, \mathrm{o}}$; the resulting value of $d_{\mathrm{r}}$ is subtracted from $100 \%$ to yield a small number for good agreement. An extended interval of confidence in the range between 0.25 and 4 of the observation points has been also considered in the analysis. Table 3 summarizes the values of $d_{\mathrm{r}}$ for the different adopted field and laboratory data sets. A low discrepancy is obtained within the extended interval of confidence between 0.25 and 4 , where most of the data points are included.

\begin{tabular}{|c|c|c|c|}
\hline Data set & $n$ & $\begin{array}{c}d_{\mathrm{r}}(\%) \text { - data with } Q_{\mathrm{LT}, \mathrm{C}} / Q_{\mathrm{LT}, \mathrm{o}} \text { in the } \\
\text { range }[0.5,2]\end{array}$ & $\begin{array}{c}d_{r}(\%) \text { - data with } Q_{\mathrm{LT}, \mathrm{c}} / Q_{\mathrm{LT}, \mathrm{o}} \text { in the } \\
\text { range }[0.25,4]\end{array}$ \\
\hline${ }^{\mathrm{a}}$ Shoream, UK & 4 & 25 & 25 \\
\hline${ }^{\mathrm{a}}$ Hurst Castle Spit, UK & 2 & 50 & 0 \\
\hline $\begin{array}{l}\text { DVan Hijum and } \\
\text { Pilarczyk (1982) }\end{array}$ & 10 & 20 & 0 \\
\hline Total & 16 & 25 & 6.25 \\
\hline
\end{tabular}

${ }^{a}$ data adopted for verification of the GLT model.

bdata adopted for calibration of the GLT model. 
GLT COMPARISON WITH VAN RIJN (2014) FORMULA

The predictive capability of the GLT model has been verified against an alternative general formula for the LT estimation at shingle beaches (Van Rijn, 2014).

Figure 3 shows the calculated and observed values of $Q_{\mathrm{LT}}$ together with the two considered intervals of confidence for GLT and Van Rijn (2014) formulae.

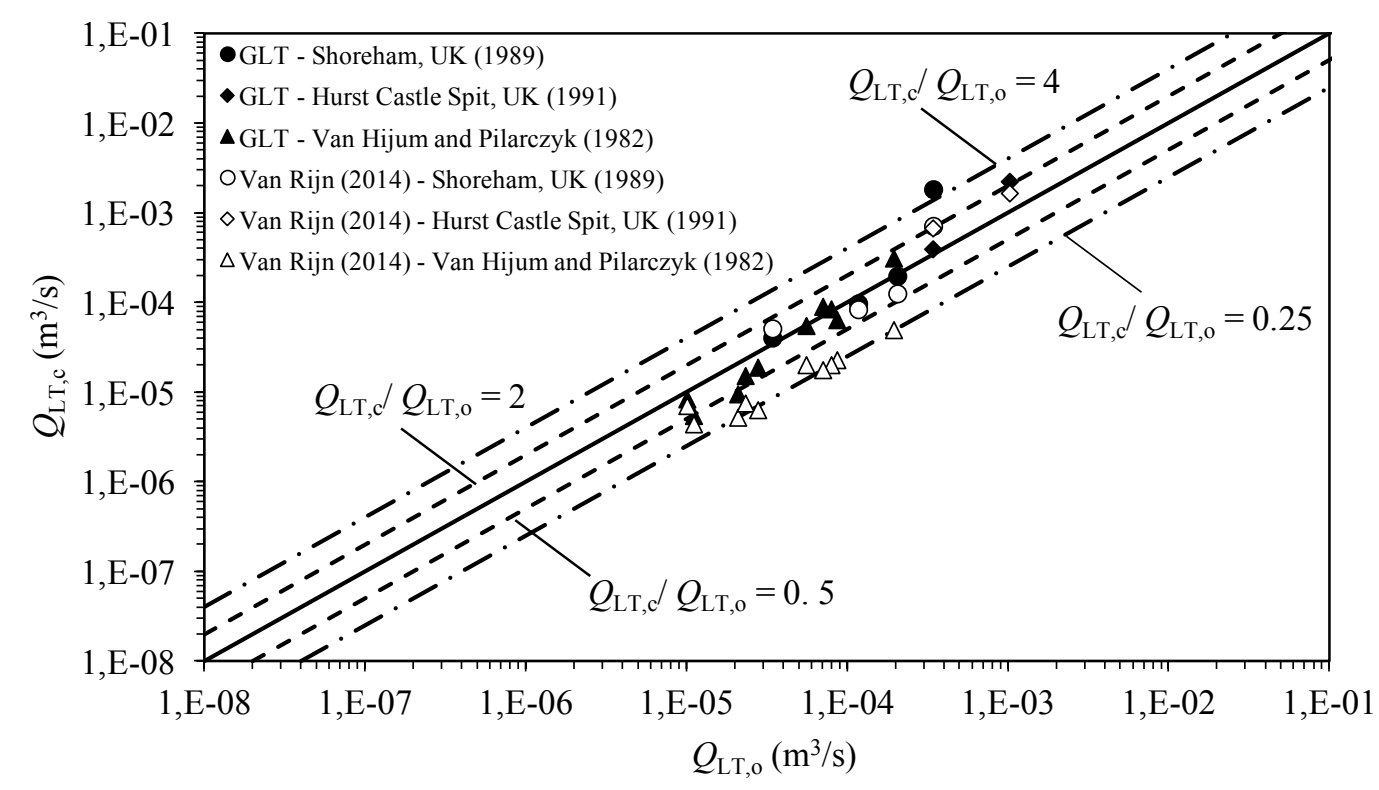

Figure 3. Calculated versus observed LT $\left(\mathrm{m}^{3} / \mathrm{s}\right)$.

The estimated $d_{\mathrm{r}}$ values for the investigated Van Rijn (2014) formula are shown in Table 4.

\begin{tabular}{|c|c|c|c|}
\hline \multicolumn{6}{|c|}{ Table 4. Capability of the Van Rijn (2014) formula. } \\
\hline Data set & $n$ & $\begin{array}{c}d_{\mathrm{r}}(\%)-\text { data with } Q_{\mathrm{LT}, \mathrm{c}} / Q_{\mathrm{LT}, \mathrm{o}} \text { in the } \\
\text { range }[0.5,2]\end{array}$ & $\begin{array}{c}d_{\mathrm{r}}(\%)-\text { data with } Q_{\mathrm{LT}, \mathrm{C}} / Q_{\mathrm{LT}, \mathrm{o}} \text { in the } \\
\text { range }[0.25,4]\end{array}$ \\
\hline${ }^{\mathrm{a}}$ Shoream, UK & 4 & 0 & 0 \\
\hline${ }^{\mathrm{a}}$ Hurst Castle Spit, UK & 2 & 0 & 60 \\
\hline $\begin{array}{c}\mathrm{b} \text { Van Hijum and } \\
\text { Pilarczyk (1982) }\end{array}$ & 10 & 90 & 37.5 \\
\hline Total & 16 & 56.25 & 0 \\
\hline
\end{tabular}

ada adopted for calibration of the Van Rijn (2014) formula.

bdata adopted for verification of the Van Rijn (2014) formula.

Comparison of the results in Figure 3 and summarized in Tables 3, and 4 reveals that the proposed GLT model exhibits the smallest $d_{\mathrm{r}}$ compared to the Van Rijn (2014) formula.

\section{LT AT A MIXED SAND AND GRAVEL BEACH}

Mixed sand and gravel beaches are beaches consisting of high proportions of both coarse particles and sand, with there being an intimate mixing of the two size fractions in the beach deposit.

Mixed beach, with poorly sorted grains of multiple sizes, are a common and globally distributed shoreline type. Despite this, rates and mechanisms of sediment transport on mixed beaches are poorly understood.

Mixed sand and gravel beaches are similar in form to gravel beaches, but the morphodynamics of the mixed beaches are distinct and potentially more complex than either sand or gravel beaches (Pontee et al., 2004; Ivamy and Kench, 2006).

In the present paper, the suitability of the GLT model, even for the mixed beach case, has been assessed by means of the comparison between the LT prediction and the observation from a field experiment on a mixed sand and gravel beach at Hawke's Bay, on the east coast of New Zealand (Komar, 2010; Dickson et al., 2011).

Figure 4 compares the orientations of two littoral cells, Bay View and Haumoana, respectively, with the dominant southeast waves (shown by the wave rays). 


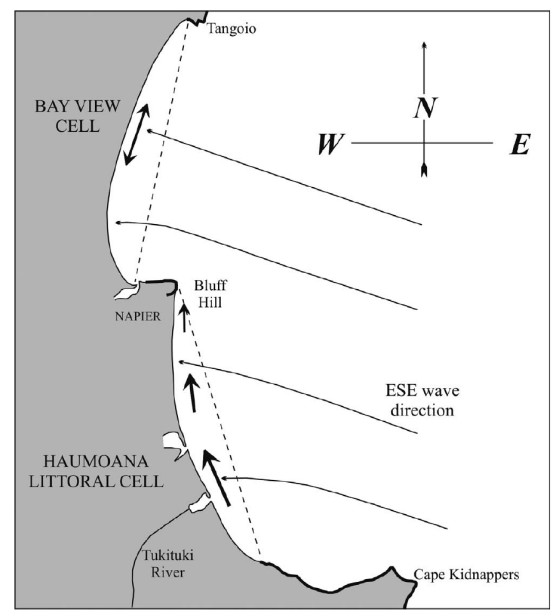

Figure 4. Orientations of the shores of the Bay View and Haumoana littoral cells, compared with the directions (wave rays) of the prevailing waves. The arrows denote the patterns of the longshore sediment transport (Komar, 2010).

The sediment composition varies from fine sand to very coarse elements with diameters ranging between $0.17 \mathrm{~mm}$ and $64 \mathrm{~mm}$.

Multiple factors have affected the Hawke's Bay shore and the locally induced beach and property erosion. An examination of the credits and debits in the sediment budget for the Haumoana cell, shown in Table 5, reveals that the debits are substantially greater than credits, with the net balance being $45,000 \mathrm{~m}^{3} / \mathrm{yr}$. Specifically, the net balance of $-45,000 \mathrm{~m}^{3} / \mathrm{yr}$ has been obtained directly from the beach profiles collected over the years by the monitoring program, and, as a result, this value is one of the more confident assessments in the budget (Tonkin and Taylor, 2005).

\begin{tabular}{|l|l|}
\hline \multicolumn{1}{|c|}{ Table 5. The sediment budget for the Haumoana littoral cell.* } \\
\hline Budget components & \multicolumn{1}{|c|}{ Estimated annual rates ( $\left.{ }^{3} / \mathrm{yr}\right)$} \\
\hline Sources (credits) & \\
\hline Tukituki River & 28,000 \\
\hline Cape Kidnappers erosion & 18,000 \\
\hline Total & 46,000 \\
\hline Losses (debits) & \\
\hline Awatoto extraction & $-47,800$ \\
\hline Pacific Beach extraction & $-12,800$ \\
\hline Gravel abrasion & $-30,400$ \\
\hline Total & $-91,000$ \\
\hline Net balance of beach sediments & $-45,000$ \\
\hline${ }^{*}$ Modified from Tonkin and Taylor (2005) \\
\hline
\end{tabular}

The estimated mean sediment volume by GLT model was about $23,000 \mathrm{~m}^{3} / \mathrm{yr}$ for a mean annual value of $H_{\mathrm{s}}$ when $D_{\mathrm{n} 50}=32 \mathrm{~mm}$. Possible reasons for disagreement can be found in $(i)$ defining of the mound material in the GLT: i.e. sorting, porosity; (ii) a missing extensive information on wave climate and (iii) considered field data limitations (large influence from human activities). According to the latest point, sediment budget was affected by environmental impacts of human interventions.

\section{CONCLUSIONS}

The GLT model and the Van Rijn (2014) expression represent the only two available general formulae in literature for the estimation of LT at sand, gravel and shingle beaches.

The GLT model belongs to the category based on an energy flux approach: in fact, the relevant wave parameter is the onshore energy flux giving the dependency of the longshore transport phenomena from the wave period (Tomasicchio et al., 2013). Similarly to the CERC formula (U.S. Army Corps of Engineers, USACE, 1984), the GLT model does not depend on the slope of the beach profile; this absence eliminates a source of uncertainty.

Van Rijn (2014) formula does not take into account the influence of the wave period of irregular 
wind waves; influence of wave period is taken into account for regular swell waves solely by means of a swell correction factor. Moreover, the author indicates a significant underprediction of LT in the case of very low waves at shingle beaches which is justified by neglecting the longshore transport at the swash zone above the mean waterline.

The verification of the two procedures, without any further calibration, has been conducted against two field and one laboratory data sets. In most cases the GLT predicted LT rates within a factor of 2 of the observed values. Van Rijn (2014) formula gave results which are slightly smaller than the laboratory observations (Van Hijum and Pilarczyk, 1982). The estimated $d_{\mathrm{r}}$ values showed that the GLT model gives a better agreement with the observed data with respect to the other investigated formula.

In addition, the suitability of the GLT model, even for the mixed beach case, has been assessed by means of the comparison between the LT prediction and the observation from a field experiment on a mixed sand and gravel beach at Hawke's Bay, on the east coast of New Zealand.

\section{REFERENCES}

Bayram, A., M. Larson, H. Hanson. 2007. A new formula for the total longshore sediment transport rate, Coastal Engineering, 54(9), 700-710.

Bramato, S., M. Ortega-Sanchez, C. Mans, M.A. Losada. 2012. Natural recovery of a mixed sand and gravel beach after a sequence of a short duration storm and moderate sea states, Journal of Coastal Research, 28, 89-101.

Chadwick, A.J. 1989. Field Measurements and Numerical Model Verification of Coastal Shingle Transport, BHRA, The Fluid Engineering Centre, UK, pp. 381-402 (Chapter 27).

Dake, J.M.K. 1972. Essential Engineering Hydraulics. MacMillan Intern. College Edition.

Dickson, M.E., P.S. Kench, M.S. Kantor. 2011. Longshore transport of cobbles on a mixed sand and gravel beach, southern Hawke Bay, New Zealand, Marine Geology, 287, 31-42.

Ivamy, M.C., P.S. Kench. 2006. Hydrodynamics and morphological adjustment of a mixed sand and gravel beach, Torere, Bay of Plenty, New Zealand, Marine Geology, 228, 137-152.

Kamphuis, J.W. 1991. Alongshore sediment transport rate, Journal of Waterway, Port, Coastal and Ocean Engineering, ASCE, 117, 624-640.

Komar, P.D. 2010. Shoreline evolution and management of Hawke's Bay, New Zeland: tectonics, coastal processes, and human impacts, Journal of Coastal Research, 26(1), 143-156.

Komar, P.D., M.K. Gaughan. 1972. Airy wave theory and breaker height prediction, Proceedings of the $13^{\text {th }}$ International Conference on Coastal Engineering, ASCE, Vancouver, pp. 405-418.

Lamberti, A., G.R. Tomasicchio. 1997. Stonemobility and longshore transport at reshaping breakwaters, Coastal Engineering, 29(3), 263-289.

Nicholls, R.J., P. Wright. 1991. Longshore transport of pebbles: experimental estimates of K, Proceedings of Coastal Sediments '91, ASCE, pp. 920-933.

Pontee, N.I., K. Pye, S.J. Blott. 2004. Morphodynamic behaviour and sedimentary variation of mixed sand and gravel beaches, Suffolk, UK, Journal of Coastal Research, 20, 256-276.

Tomasicchio, G.R., A. Lamberti, F. Guiducci. 1994. Stone movement on a reshaped profile, Proceedings of the $24^{\text {th }}$ International Conference on Coastal Engineering, ASCE, Kobe, pp. 16251640.

Tomasicchio, G.R., R. Archetti, F. D'Alessandro, P. Sloth. 2007. Long-shore transport at berm breakwaters and gravel beaches, Proceedings of the International Conference Coastal Structures '07, World Scientific, Venice, pp. 65-76.

Tomasicchio, G.R., F. D'Alessandro, F. Musci. 2010. A multi-layer capping of a coastal area contaminated with materials dangerous to health, Chemistry and Ecology 26(1), 155-168.

Tomasicchio, G.R., F. D'Alessandro, G. Barbaro, G. Malara. 2013. General longshore transport model, Coastal Engineering, 71(1), 28-36.

Tomasicchio, G.R., F. D’Alessandro, G. Barbaro, E. Musci, T.M. De Giosa. 2015. General longshore transport model at shingle beaches: an independent verification, Coastal Engineering, 104, 69-75.

Tonkin and Taylor, 2005. Shoreline Modelling Report. Report to the Hawke's Bay Regional Council, Christchurch, New Zealand: Tonkin \& Taylor.

U.S. Army Corps of Engineers (USACE), 1984. Shore Protection Manual. U.S. Army Corps of Engineers Research and Development Center. Coastal and Hydraulics Laboratory, Vicksburg.

Van Hijum, E., K.W. Pilarczyk. 1982. Equilibrium profile and longshore transport of coarse material under regular and irregular wave attack. Delft Hydraulics Laboratory, Netherlands, Publication n. 274. 
Van Rijn, L.C. 2007. Unified view of sediment transport by currents and waves, IV: application of morphodynamic model, Journal of Hydraulic Engineering, ASCE 133(7), 776-793.

Van Rijn, L.C. 2006, 2012. Principles of Sedimentation and Erosion Engineering in Rivers, Estuaries and Coastal Seas, Aqua Publications, The Netherlands (www.aquapublications.nl).

Van Rijn, L.C. 2014. A simple general expression for longshore transport of sand, gravel and shingle, Coastal Engineering, 90, 23-39.

Van Rijn, L.C., D.J.R. Walstra, B. Grasmeijer, J. Sutherland, S. Pan, J.P. Sierra. 2003. The predictability of cross-shore bed evolution of sandy beaches at the time scale of storms and seasons using process-based models, Coastal Engineering, 47, 295-327.

Van Rijn, L.C., P.K. Tonnon, D.J.R. Walstra. 2011. Numerical modelling of erosion and accretion of plane sloping beaches at different scales, Coastal Engineering, 58, 637-655.

Van Wellen, E., A.J. Chadwick, T. Mason. 2000. A review and assessment of longshore sediment transport equations for coarse-grained beaches, Coastal Engineering, 40(3), 243-275. 